\title{
Knjiga za naročje kot alternativno učno okolje za namene diferenciacije pri pouku tujega jezika
}

\author{
Katarina Benedik \\ Osnovna šola Železniki \\ katarina.benedik@gmail.com
}

\section{Silva Bratož}

Univerza na Primorskem

silva.bratoz@pef.upr.si

\section{Anja Pirih \\ Univerza na Primorskem \\ anja.pirih@fhs.upr.si}

\begin{abstract}
Heterogeni razredi predstavljajo za učitelje, ki želijo vsem svojim učencem zagotovili enake možnosti za usvajanje znanja, precejšen izziv. Učinkovit odgovor nanj predstavlja oblikovanje učnega okolja po načelih diferenciacije in individualizacije. V prispevku predstavljamo primer oblikovanja takšnega okolja za namene diferenciacije pri pouku angleščine kot tujega jezika v nižjih razredih osnovne šole na osnovi formata knjige za naročje (angl. lap book). Pripomoček smo preizkusili z učenci četrtega razreda ene izmed slovenskih osnovnih šol in na podlagi njihove povratne informacije lahko zaključimo, da je primeren za vključevanje vseh učencev ne glede na njihovo predznanje, stopnjo jezikovne sporazumevalne zmožnosti, interese in učne stile. Učenci so v diferencirano okolje knjige za naročje lahko prehajali med poukom ali v času odmora. Posebej pozitivno so se odzvali na dejavnosti, zasnovane po načelu igre, $z$ izraženo socialno in sodelovalno komponento ter na avtonomijo pri uporabi pripomočka.
\end{abstract}

Ključne besede: knjiga za naročje, alternativno učno okolje, diferenciacija, učenje tujega jezika, osnovna šola

\section{Uvod}

Tako v Sloveniji kot drugod po svetu se učitelji na vseh stopnjah izobraževanja srečujejo z bolj ali manj heterogenimi razredi in učenci z izredno raznolikimi sposobnostmi ter potrebami (Brewster, Ellis in Girard 2010). Že pri učencih prvega vzgojno-izobraževalnega obdobja osnovne šole (v nadaljevanju OŠ) lahko opazimo razlike v znanju, obvladovanju postopkov, stališčih, zanimanjih in učni motivaciji, razlikujejo pa se tudi glede na učne stile in osebno- 
stne lastnosti (Lightbown in Spada 2013). Da bi v pouk lahko uspešno vključevali vse učence in jim tako zagotovili enake možnosti za usvajanje znanja, skušajo učitelji pouk diferencirati in individualizirati (več o tem v naslednjem poglavju).

Ko govorimo o personalizaciji in individualizaciji učenja, $v$ ospredje vedno bolj stopajo diskusije o oblikovanju učinkovitih učnih okolij, ki bi bila v kar največji meri prilagojena individualnim razlikam učencev, ki vanje vstopajo, in za oblikovanje katerih je vsaj soodgovoren, če ne kar odgovoren, učitelj (Dumont, Istance in Benavides 2013). Vodilni projekt Centra OECD za raziskave in inovacije v izobraževanju je tako projekt Inovativna učna okolja (Innovative Learning Environments - ILE), ki obravnava predvsem inovativne načine organiziranja učenja za mlade in skuša podati dokaze, zakaj so taka okolja uspešna. Pri tem med drugim poudarja prepoznavanje učencev kot ključnih udeležencev $v$ učnem procesu in njihovo aktivno vključevanje v učenje ter pomen individualnih razlik med njimi, še posebej motivacije in predznanja (OECD 2013). Ni torej presenetljivo, da se od sodobnih učnih okolij, tako konceptualnih kot tudi fizičnih in virtualnih, pričakuje ravno sposobnost prilagajanja dejavnosti in tempa individualnim razlikam ter napredku posameznega učenca in skupine kot celote. Pri tem imajo pomembno vlogo ustrezni pristopi in metode dela, vključno z ustreznimi didaktičnimi sredstvi.

Namen pričujočega prispevka je predstaviti primer dobre prakse, in sicer izdelavo didaktičnega sredstva knjiga za naročje (angl. lap book), ki deluje kot alternativno učno okolje za namene diferenciacije pri pouku tujega jezika v drugi triadi OŠ. Pripomoček je bil preizkušen v četrtem razredu ene izmed gorenjskih osnovnih šol. V raziskavi je sodelovalo 20 učencev, ki so septembra 2020 spoznali knjigo za naročje Jobs in se tri tedne z njo samostojno učili. Učenci so imeli možnost prehajanja $v$ alternativno učno okolje knjige za naročje tako med poukom kot v času odmorov. Po zaključku uporabe didaktičnega pripomočka smo $z$ vprašalnikom ugotavljali njihovo splošno mnenje o knjigi za naročje, vpliv na njihovo učno motivacijo in mnenje o učni temi ter težavnostnih stopnjah. Vprašalnik obsega šest sklopov z vprašanji zaprtega in odprtega tipa, s trditvami na tristopenjski lestvici in $z$ dokončanjem povedi. Pridobljeni rezultati so bili deskriptivno analizirani in so predstavljeni v sklopu evalvacije didaktičnega pripomočka.

\section{Diferenciacija in individualizacija pouka}

$Z$ diferenciacijo poučevanje prilagajamo posameznim učencem oz. manjšim skupinam učencev tako, da spodbujamo njihova močnejša področja, prilagajamo učni tempo, stopnjo zahtevnosti in način poučevanja (Heacox 2009). 
Kot poudarja Tomlinsonova (2001; 2003), je diferencirano poučevanje odzivno poučevanje, pri čemer učitelj upošteva in se odziva na pripravljenost (znanje, razumevanje in spretnosti), zanimanje, učni stil in samopodobo svojih učencev, ne da bi pri tem pouk »drobil« na ločene, individualne ravni. Strmčnik $(1987,13)$ po drugi strani diferenciacijo vidi bolj kot organizacijski ukrep, ki služi za lažje izvajanje individualizacije, to pa definira kot »didaktično načelo, ki zahteva od šole in učitelja, da odkrivata, spoštujeta in razvijata utemeljene individualne razlike med učenci, da skušata sicer skupno poučevanje in učenje čim bolj individualizirati in personificirati«.

Diferenciacija in individualizacija sta nujni tudi pri pouku tujega jezika, saj so skupine že v prvem razredu OŠ glede jezikovnega predznanja zelo heterogene, razlike pa še dodatno povečujejo individualne karakteristike učencev, še posebej nadarjenost za učenje jezikov, različne inteligentnosti, osebnostne lastnosti, npr. tesnobnost, ter stališča in učna motivacija (Lightbown in Spada 2013). Učitelji lahko pri pouku tujega jezika prilagajajo vsebino, proces učenja, izdelke učencev ali učno okolje (Tomlinson 200o). Vsebino lahko diferencirajo ali individualizirajo predvsem z uporabo različnih težavnostnih stopenj in raznolikih sredstev, ki ustrezajo različnim inteligentnostim in učnim stilom. Pri prilagoditvah procesa učenja v le-tega vključujemo ustrezne podporne strategije in naloge na različnih ravneh zahtevnosti, pri tem pa smo pozorni na različen čas izvajanja dejavnosti ter na spodbujanje osebnih interesov, ki učencu zvišajo raven motivacije za učenje. Pri izdelkih učencem dovolimo, da sami izdelajo gradivo, ki jim omogoča lažje učenje ali predstavitev znanja, pri tem pa poskrbimo, da se učne teme ujemajo z njihovimi interesi in da so izdelki pripravljeni v skladu $z$ danimi navodili. Pri prilagajanju učnega okolja pa je zelo pomembno, da učencem $v$ učilnici zagotovimo miren kotiček za individualno delo ter kotiček za druženje in delo v skupini, prav tako pa so dobrodošle rutinske dejavnosti za tisti del ure, ko je učitelj zaposlen $\mathrm{s}$ pomočjo drugim učencem (Tomlinson 2000). Z naštetimi prilagoditvami se učitelji trudijo, da bi pouk čim bolj približali vsem učencem in se čim bolj odzvali na vse njihove potrebe (Heacox 2009; Tomlinson 2000), da ne bi niti učenci z višjo ravnjo jezikovne sporazumevalne zmožnosti niti tisti z nižjo izgubili motivacije za učenje tujega jezika.

Govorimo lahko o različnih vrstah učne diferenciacije in individualizacije, in sicer o notranji, fleksibilni in zunanji (Strmčnik 2001). Zunanja diferenciacija, tako popolna (angl. streaming) kot tudi delna (angl. setting), se največkrat uporablja v višjih razredih OŠ, pri čemer so učenci glede na svoje sposobnosti in hitrost usvajanja novega znanja razporejeni v enotne skupine, pri katerih se razlikujejo tudi učni cilji in vsebine. Zunanje diferencirane skupine lahko 
posledično vodijo do razlik v možnostih nadaljnjega izobraževanja. Za fleksibilno obliko so značilne tako raznovrstne kot tudi enovrstne skupine, pri tem pa se prepletata temeljni in nivojski pouk, npr. pri občasnem timskem delu (Strmčnik 2001). Pri notranji diferenciaciji in individualizaciji si prizadevamo ohraniti heterogenost skupin ali razredov brez delitve na manjše homogene skupine, pri tem pa za posamezne učence izbiramo različne učne cilje in vsebine, različne metode in oblike učenja, raznolika didaktična sredstva, vključujemo pa tudi učno pomoč (Lesničar 2004; Strmčnik 2001).

Raziskave (Valenčič Zuljan idr. 2012; Ireson in Hallam 2001) so pokazale, da je za nižje razrede OŠ najprimernejša notranja oblika diferenciacije in individualizacije, samo ta oblika je za to stopnjo predvidena tudi v Zakonu o osnovni šoli (2006) in Pravilniku o izvajanju diferenciacije v osnovni šoli (2006). Notranja oblika diferenciacije in individualizacije je tudi najzahtevnejša za izvedbo v razredu, saj je potrebno upoštevati vse elemente učnega procesa in značilnosti razreda (Lesničar 2004; Strmčnik 2001), od učitelja pa zahteva pogosto diferenciranje učnih nalog, didaktičnih sredstev, modelov in navodil, ki jih damo učencem. Ob tem je potrebno učencem pustiti čas, ki ga potrebujejo za dobro opravljeno delo, kar velikokrat rešujemo s skupinskim delom, z delom v parih, še najlažje in najučinkoviteje pa s samostojnim delom (Strmčnik 2001). Individualne učne oblike dela učitelji pri pouku tujega jezika, razen ob samostojnem reševanju nalog, ne uporabljajo pogosto, saj je zahtevnejša za izvedbo. Učenci pa ob individualnem delu lahko sami prilagajajo tempo učenja, težavnost dejavnosti, s tem pa se jim poviša tudi stopnja motivacije za učenje tujega jezika.

\section{Učinkovita učna okolja}

Učno okolje je pomemben dejavnik učenja, ki lahko otrokovo pridobivanje znanja in razvijanje veščin podpira in spodbuja ali pa ovira. Stonehousova (2011) tako o učnem okolju govori kot o tretjem učitelju, ki poleg vrstnikov in odraslih vpliva na vedenje vseh, ki so vključeni v učni proces. Čeprav se Stonehousova v svojem prispevku omeji na fizično okolje, se strokovnjaki na področju učenja strinjajo, da sodobno pojmovanje učnega okolja presega pojma fizično ali tehnološko okolje za učenje in prej govori o kontekstu učenja, ki zajema dinamiko in odnose med učencem, učiteljem, vsebino ter opremo in tehnologijo (Dumont, Istance in Benavides 2013).

V publikaciji O naravi učenja (Dumont, Istance in Benavides 2013) so predstavljena načela, ki se nanašajo na inovativna učna okolja: postaviti učenje $v$ središče, spodbujati zavzetost in razviti prostor, kjer se učenci prepoznajo za učeče se, zagotavljati socialno in sodelovalno dimenzijo učenja, poznati mo- 
tivacijo učencev in se zavedati pomena čustev za učenje, biti občutljivi za individualne razlike med učenci, tudi v njihovem predznanju, postavljati visoka pričakovanja do vsakega učenca, ki pa so skladna z njegovimi zmožnostmi, delovati $v$ skladu z jasno določenimi cilji in uporabljati načine ocenjevanja, $\mathrm{ki}$ so $v$ skladu z njimi, z močnim poudarkom na formativni povratni informaciji, ter spodbujati povezanost med področji znanja in predmeti $v$ vrtcu, šoli in zunaj nje. Okolje, oblikovano v skladu s temi načeli, prispeva $\mathrm{h}$ konstruktivnemu, $\mathrm{k}$ samoreguliranemu in sodelovalnemu učenju.

$Z$ vedno večjo vlogo digitalne tehnologije pri učenju se v zadnjem obdobju uveljavlja termin prostori učenja (angl. learning spaces), ki poudarja interakcijo med učečimi se, učnimi viri in (digitalnimi) orodji, pri čemer imajo ključno vlogo učenci (Damşa, Nerland in Andreadakis 2019). Za takšne prostore učenja je značilno, da so nematerialni prostori akcije, kjer se oblikujejo učenčevi cilji, znanje in delovanje. Delno jih predhodno oblikuje učitelj sam, vendar jih vedno konstruira tudi učenec, pri čemer je zelo pomembna njegova avtonomija. Pomembno za prostore učenja je, da znotraj njih učeči se vzpostavlja odnose z viri, npr. znanjem, ljudmi, gradivi, v lokalnem in razširjenem izvenšolskem kontekstu. Podporo prostorom učenja pa zagotavlja okvir, ki ga vzpostavljata izobraževalni kontekst s svojo institucionalno, materialno in digitalno infrastrukturo ter pedagoška ureditev (npr. vloga učitelja) (Damşa, Nerland in Andreadakis 2019).

\section{Knjiga za naročje kot alternativno učno okolje za namene diferenciacije}

Izdelali smo pripomoček, ki služi kot alternativno učno okolje. To Langejeva in Slettenova (2002) opredelita kot »šolo znotraj šole«. Ta učencu znotraj širšega učnega okolja posamezne šole omogoči izkušnjo pripadnosti manjši skupnosti, s katero deli izobraževalne potrebe in interese. Odločili smo se za format knjige za naročje (angl. lap book; gl. poglavje »Lastnosti knjige za naročje«), ki je v Sloveniji še neuveljavljeno didaktično sredstvo, $v$ tujini pa se uporablja predvsem za šolanje na domu, zato se zdi primerno za učno okolje, prilagojeno individualnim razlikam med učenci in diferenciaciji pouka.

Pri snovanju in izdelavi knjige za naročje sledimo naslednjim korakom: (1) izbira vsebinskega področja in načrtovanje učnih ciljev; (2) oblikovanje dejavnosti po kriterijih za inovativna učna okolja in prostore učenja (Dumont, Istance in Benavides 2013; Damşa, Nerland in Andreadakis 2019), s posebnim poudarkom na diferenciaciji; (3) izbira materialov, oblikovanje pripomočka; (4) izdelava knjige za naročje, pripadajočih gradiv in dejavnosti; (5) evalvacija pripomočka v razredni praksi. 


\section{Lastnosti knjige za naročje}

Knjiga za naročje je pripomoček v obliki knjige/mape večjega formata, ki jo učenec drži v naročju (Whittaker 2008; Hudson 2014). Knjiga je zbirnik različnih dejavnosti na izbrano učno temo, te pa so oblikovane kot zbirka žepkov, zavihkov, manjših knjig oz. prikazov in dejavnosti (slika 1), ki ustvarjajo prostor učenja (Whittaker 2008). Kot didaktično sredstvo oz. »didaktično oblikovana objektivna stvarnost « (Poljak 1974, 66) učence spodbuja k spoznavnemu oz. kognitivnemu konfliktu in $\mathrm{s}$ tem $\mathrm{k}$ aktivni vlogi $v$ učnem procesu. Bistvenega pomena je, da so dejavnosti interaktivne in praktično oblikovane (Hudson 2014), knjiga pa se lahko ves čas spreminja in dopolnjuje.

Uporaba knjige za naročje je primerna za učence vseh starosti. Starejši učenci lahko knjigo izdelajo sami, mlajšim ponudimo že izdelano učilo ali predlogo, ki jo dopolnjujejo s svojimi izdelki, celo za najmlajše, ki še niso opismenjeni, lahko izdelamo knjigo, v kateri prevladujejo podobe, igrice, pesmice ipd. Prav tako imamo ob izbiri teme neskončno možnosti, saj jo lahko oblikujemo za različna predmetna področja (Whittaker 2008). Če knjigo za naročje izdelajo učenci sami v obliki zbirnika izdelkov na določeno temo (portfolia), jo lahko učinkovito uporabimo tudi za preverjanje in ocenjevanje znanja, saj predstavlja konkreten dokaz o znanju učencev, spodbuja pa tudi njihovo motivacijo in aktivno vključevanje $v$ učni proces, $s$ tem pa tudi njihovo samostojnost (Pinter 2006). Knjige za naročje se v tujini pogosto uporabljajo pri šolanju na domu, in sicer kot ustvarjalen prikaz tako obravnavanih učnih vsebin kot tudi procesa učenja (Rickard 2017), medtem ko v slovenskem prostoru predstavljajo novost.

\section{Izbira vsebinskega področja in načrtovanje učnih ciljev}

S knjigo za naročje želimo oblikovati učno okolje, primerno za vse učence četrtega razreda OŠ ne glede na sposobnosti, potrebe, spoznavni stil, interese in motivacijo vsakega posameznega učenca. Kot poudarjajo Dumontova in sodelavci (2013), je potrebno pri oblikovanju načel, ki opredeljujejo inovativna učna okolja, delovati v skladu z jasno določenimi pričakovanji in cilji, ki pozneje definirajo tudi preverjanje znanja in posredovanje povratne informacije.

Prvi korak pri načrtovanju knjige za naročje je tako izbira teme in oblikovanje učnih ciljev. Po pregledu Učnega načrta za angleščino (Ministrstvo za izobraževanje, znanost in šport 2016) smo se odločili za temo poklicev, ki je ena od predlaganih vsebin za medpredmetno povezovanje angleščine $z$ drugimi predmeti. Na ta način smo želeli doseči horizontalno povezanost med različnimi predmetnimi področji (Dumont, Istance in Benavides 2013) z izborom predstavljenih poklicev (med drugim vplivnica, veterinarka, inštruktor 


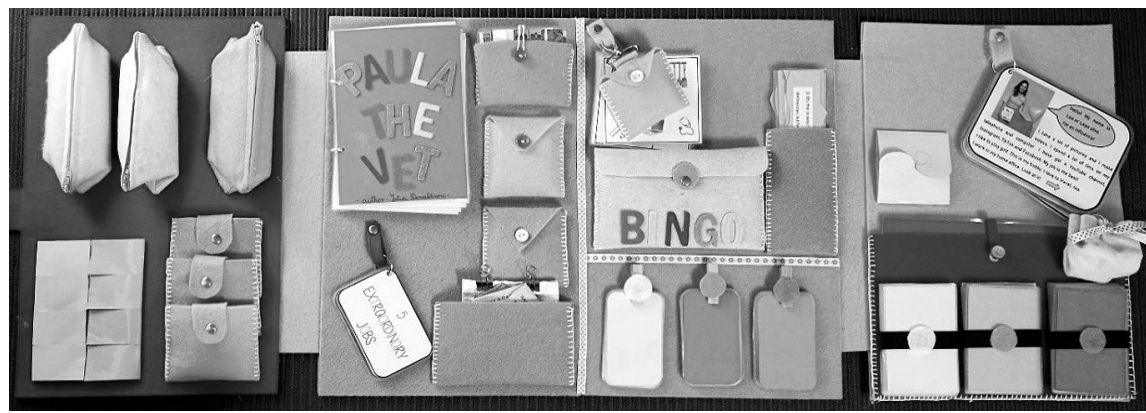

Slika 1

Notranjost knjige

za naročje Jobs

\section{Slika 2}

Zunanje platnice knjige

za naročje Jobs

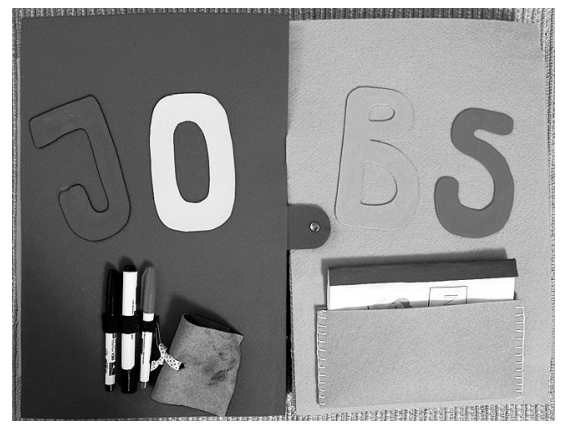

deskanja za pse) ter točno določenih realnih delovnih okolij (npr. letališče Heathrow, osnovna šola Novo mesto) pa tudi navezavo na resnično življenje izven učilnice oz. šole, kar igra ključno vlogo pri zagotavljanju relevantnosti učenja, podpira pa tudi zavzetost za učenje in motivacijo, kar so značilnosti inovativnih učnih okolij in prostorov učenja (Dumont, Istance in Benavides 2013; Damşa, Nerland in Andreadakis 2019).

Pri določanju učnih ciljev v ospredje postavljamo razvijanje besedišča, povezanega z izbrano temo, in bralno zmožnost, v manjši meri pa tudi razvijanje ostalih sporazumevalnih zmožnosti, npr. pisno zmožnost s pisanjem krajših besedil ter slušno in govorno zmožnost pri aktivnostih, ki so oblikovane za učenje v paru ali skupini. Oblikovana knjiga za naročje je namenjena uporabi $v$ različnih fazah učenja, od seznanjanja z novo temo, spoznavanja ciljnega jezika v smiselnem kontekstu, vodene vadbe in samostojne rabe jezika do preverjanja in ocenjevanja znanja.

\section{Oblikovanje diferenciranih dejavnosti po kriterijih za inovativna učna okolja}

Pri oblikovanju dejavnosti v knjigi veliko pozornosti namenjamo diferenciaciji in individualizaciji učenja, kar je v skladu $z$ več načeli oblikovanja inovativnih učnih okolij, in sicer občutljivostjo za individualne razlike med učenci 
(npr. razlike v predznanju), upoštevanjem motivacije učencev in pomena čustev za učenje ter zagotavljanjem izzivov, skladnih z učenčevimi zmožnostmi (Dumont, Istance in Benavides 2013).

Dejavnosti so zasnovane tako, da vključujejo raznotere inteligentnosti (Brewster, Ellis in Girard 2010), npr. sestavljanje povedi za učence $z$ razvito jezikovno pa tudi logično-matematično inteligentnostjo, branje zgodbe $z$ rimami za učence $z$ razvito glasbeno in jezikovno inteligentnostjo ipd. Prav tako želimo $z$ oblikovanimi aktivnostmi zagotoviti primerno stopnjo kognitivnega izziva za učence $z$ različnim predznanjem in različnimi ravnmi jezikovne sporazumevalne zmožnosti, zato je večina dejavnosti oblikovana na treh različnih težavnostnih stopnjah. Prvenstveno se razlikujejo glede na ponujeno podporo (verbalno, $z$ uporabo različnih pripomočkov in prikazov, $v$ manjšem obsegu tudi postopkovno (Echevarria, Vogt in Short 2004 v Bratož in Žefran 2014)), ki je je največ na najnižji težavnostni stopnji, z zviševanjem težavnosti pa tudi podporo umikamo, kot je podrobneje razloženo pri predstavitvi posameznih aktivnosti. Prav tako se težavnostne stopnje razlikujejo glede na zahtevnost besedišča in jezikovnih struktur ter jezikovne kompetence, ki jih z dejavnostjo razvijamo. Težavnostne stopnje so barvno kodirane (rumena - najlažja, zelena - srednja, modra - najtežja), kar omogoča lažjo orientacijo po gradivih in dejavnostih ter samostojno delo s knjigo za naročje. Učenci med težavnostnimi stopnjami samostojno in prosto izbirajo. Tako se lahko vračajo $k$ dejavnostim na isti težavnostni stopnji ali pa svoj napredek spremljajo tudi z izbiranjem vedno težjih različic določenih dejavnosti, z zahtevnejšimi jezikovnimi strukturami in manj podpore.

Barvno kodirane težavnostne stopnje in različne podpore, ki so integrirane $v$ dejavnosti, jasna navodila za delo, ki jih učenci najdejo v žepku na zunanji platnici knjige za naročje (slika 2), in logično strukturirane dejavnosti so med najvidnejšimi elementi knjige za naročje, ki učencem omogočajo samostojno in prosto premikanje po tem učnem okolju. Še več, z avtonomnim izbiranjem aktivnosti, vrstnega reda uporabe gradiv, interakcijo z gradivom ipd., prostor učenja, predhodno zasnovan s strani učitelja, do neke mere rekonstruirajo (Damşa, Nerland in Andreadakis 2019), pri tem pa razvijajo samoregulacijske veščine, ki jim omogočajo nadzor nad učenjem in evalvacijo znanja (Dumont, Istance in Benavides 2013).

Knjiga za naročje je izdelana iz premišljeno izbranih materialov (tj. debelejšega filca in plastificiranih gradiv, na katera je možno s flomastri pisati in zapis tudi izbrisati), kar omogoča njeno ponovno uporabo ne le s strani različnih učencev, pač pa tudi istega učenca, ki se po prejeti povratni informaciji (bodisi podani interaktivno znotraj same knjige za naročje ali s strani učitelja) 


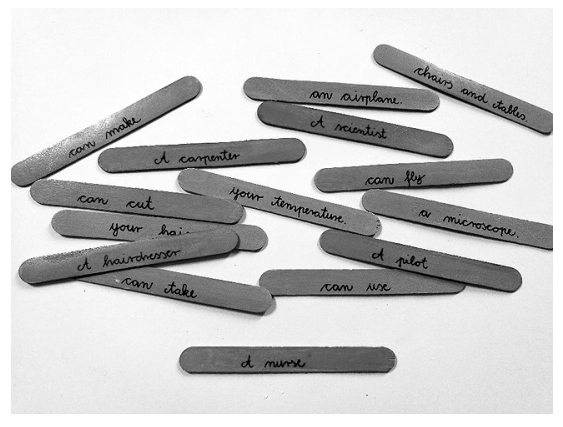

Slika 3 Sestavljanje povedi iz paličic (srednja stopnja)

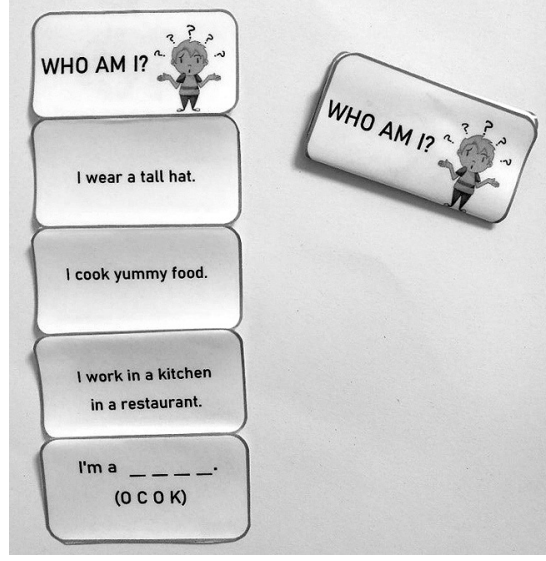

Slika 4 Zgibanke z ugankami (srednja stopnja)

lahko vrne $k$ določeni dejavnosti in jo ponovno izvede ter tako preveri svoj napredek.

Potrebno je poudariti, da z osredotočanjem na zagotavljanje diferenciacije in individualizacije učenja pozornost gotovo $v$ večji meri usmerjamo $k$ vsakemu posameznemu učencu in njegovim individualnim značilnostim, pa vendar pri oblikovanju knjige za naročje sledimo tudi načelu zagotavljanja socialne in sodelovalne dimenzije učenja. $Z$ dejavnostmi, ki omogočajo učenje v paru ali manjši skupini, omogočamo vzpostavitev procesov interakcije, pogajanja in sodelovanja, ki so nujni tudi pri konstrukciji znanja (Dumont, Istance in Benavides 2013). S sodelovanjem v manjši skupini, ki se oblikuje v kontekstu knjige za naročje, pa dobi učenec izkušnjo alternativnega učnega okolja oz. »šole znotraj šole« (Lange in Sletten 2002).

$\checkmark$ nadaljevanju podrobneje predstavljamo dejavnosti, ki so vključene $v$ knjigo za naročje Jobs.

Sestavljanje povedi. Učencem so na voljo trije kompleti lesenih paličic, s katerimi sestavljajo smiselne povedi. Takšen tip dejavnosti ustreza učencem z razvito jezikovno inteligentnostjo, saj imajo dobro razvit besedni zaklad in med seboj lažje povezujejo besede ali besedne zveze, medtem ko učenci z razvito logično-matematično inteligentnostjo ob urejanju paličic lahko opazujejo vzorce (Brewster, Ellis in Girard 2010), po katerih so oblikovane povedi $v$ angleščini. Na vsaki težavnosti stopnji lahko sestavijo pet povedi, vezanih na dejavnosti posameznih poklicev. Na najlažji stopnji povezujejo samostalnik (izraz za poklic) z glagolom (dejanjem, ki ga ta poklic izvaja) (npr. A baker can bake.), pri srednji težavnostni stopnji (slika 3) smo uporabili zahtevnejše 
besedišče in dodali še nadaljevanje povedi (npr. A nurse can take your temperature.), na najzahtevnejši stopnji pa morajo učenci samostojno sestaviti poved v pravilnem vrstnem redu, pri čemer je vsaka beseda na svoji palčki, vključno s členi in z modalnimi glagoli (npr. A mechanic can fix your car.).

Slikovni slovarček poklicev. Slikovni slovarček je zasnovan tako, da učence seznanja $z$ razlikami $v$ poimenovanju poklicev $v$ angleščini glede na spol osebe, ki poklic opravlja.

Zgibanke z ugankami. V knjigo so za vsako težavnostno stopnjo vključene po štiri zgibanke o poklicih, ki delujejo kot uganke. Zgibanke se odpirajo postopno, da se lahko učenci osredotočijo le na eno poved naenkrat, povedi pa so razvrščene glede na sporočilnost - bolj kot se učenci bližajo koncu uganke, več informacij prejmejo ob prebrani povedi. Na najlažji težavnostni stopnji so na koncu uganke podani trije možni odgovori, pravilnega obkrožijo s flomastrom; na srednji težavnostni stopnji (slika 4) je rešitev podana v obliki anagrama; na modri stopnji pa učenci na koncu sami ugibajo poklic, brez dodatnih namigov, zapisati pa ga morajo z ustreznim nedoločnim členom. Zgibanke modre stopnje vsebujejo težje besede, zato učencem pri tej dejavnosti svetujemo uporabo spletnega ali običajnega slovarja.

Zgodba Paula the Vet. V knjigo so vključene dejavnosti, ki temeljijo na slikanici Julie Donaldson z naslovom Paula the Vet (2006). Zgodba je primerna predvsem zaradi številnih ponavljanj in rim, rimano besedilo pa učencem pomaga pri pravilnem naglaševanju besed (Zorman 2008). Ustreza predvsem učencem s poudarjeno glasbeno inteligentnostjo, saj so občutljivi na ritem in jim rime $v$ besedilih olajšajo učenje, pa tudi učencem $z$ razvito jezikovno inteligentnostjo, saj se ti praviloma dobro učijo ob branju zgodb in imajo dobro razvit besedni zaklad (Bratož 2017; Brewster, Ellis in Girard 2010).

Pri dejavnosti bralnega razumevanja so ilustracije ločene od besedila slikanice. Besedilo je enako izvirniku, dodali pa smo izrezane slike, ki jih učenci ob branju pritrjujejo na ustrezno mesto v knjigi (slika 5). Ponudimo jim lahko tudi izvirno slikanico, s katero preverijo ujemanje besedila in ilustracij.

$V$ tem sklopu najdemo še tri dejavnosti, ki se navezujejo na besedišče iz zgodbe in ustrezajo trem težavnostnim stopnjam. Na najlažji stopnji učenci igrajo igro spomin, pri kateri povezujejo besede $z$ ustreznimi sličicami. Igro lahko igrajo sami, v parih ali manjših skupinah. Pri srednji težavnostni stopnji povezujejo sličice $z$ besedami tako, da glasno preberejo besedo na kartici in jo poskušajo povezati z rimano besedo, ki jo predstavlja sličica. Na težavnostni stopnji modre barve pa imajo na voljo dve zgibanki v obliki cveta (slika 6). Prva zgibanka ima na zunanjih straneh zavihkov vprašanja o vsebini zgodbe Paula the Vet, učenci pa s pomočjo odgovorov pod zavihki samostojno preve- 


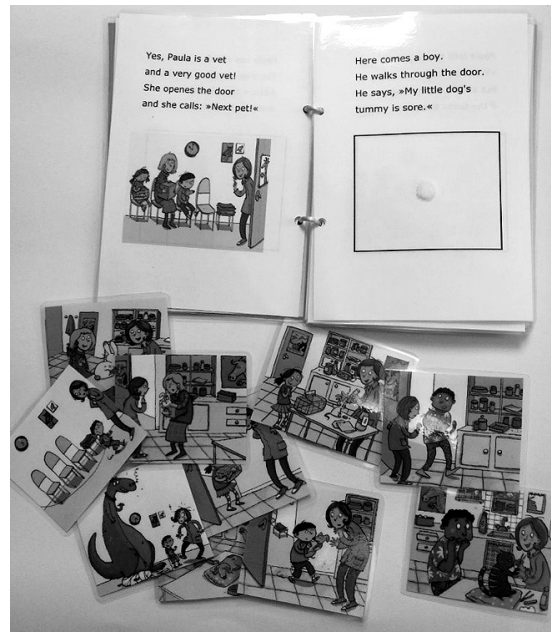

Slika 5 Knjiga Paula the Vet (Donaldson 2006)

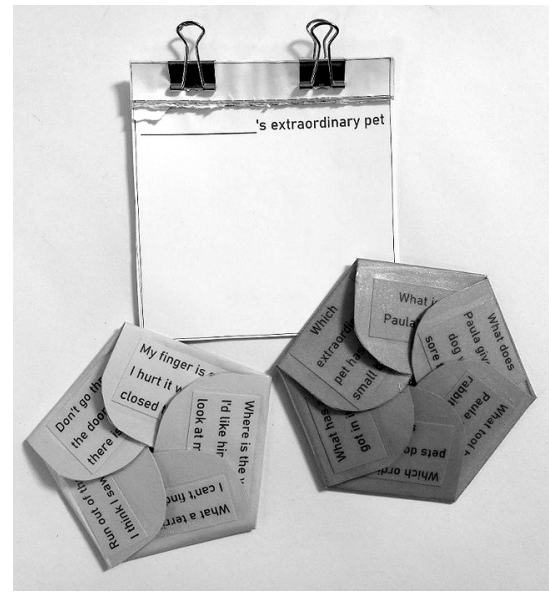

Slika 6 Zgibanki z vprašanji in rimami ter listi za risanje nenavadnega hišnega ljubljenčka

rijo razumevanje zgodbe. V sredini zgibanke jih čaka še dodatna naloga, in sicer lahko na priložene liste narišejo nenavadnega hišnega ljubljenčka. Druga zgibanka na najtežji stopnji pa je oblikovana tako, da učenci iščejo rime na povedi iz zgodbe Paula the Vet, zapisane na zavihkih (na primer My finger is sore, I hurt it when I closed the ...). Tudi tu lahko na notranji strani zavihka poiščejo rešitev.

Knjižica nenavadnih poklicev. Učencem želimo na zabaven način predstaviti tudi nekaj nenavadnih poklicev, kot sta varuška pand ali inštruktor deskanja za pse. Knjižica z opisi petih redkih poklicev (slika 7) ni členjena na težavnostne stopnje, poenostavljena kratka besedila so primerna za vse učence.

Orodja in pripomočki. V tem sklopu se osredotočamo predvsem na orodja in pripomočke, potrebne za opravljanje določenega poklica. Naloga rumene težavnostne stopnje je dejavnost razvrščanja, pri kateri učenci besede za pripomočke pripenjajo $v$ priloženo knjižico $k$ poklicu, ki pripomočke uporablja pri svojem delu (slika 8). Dejavnost na srednji težavnostni stopnji je igra tombola, ki jo učenci igrajo sami ali $z$ do sedmimi sošolci, saj imajo na voljo osem igralnih podlag $z$ besedami za pripomočke, povezane $z$ različnimi poklici. Dejavnost na najvišji težavnostni stopnji pa je sestavljanje pogovora med dvema otrokoma, ki se igrata, pogovarjata in ugibata različne poklice. $V$ zanimivem in šaljivem dialogu se pojavijo predvsem besede za orodja in pripomočke, pomešane dele pogovora pa učenci sestavijo $v$ smiselno celoto.

Domine. Učencem skozi dejavnosti in igre $v$ knjigi za naročje postopno 


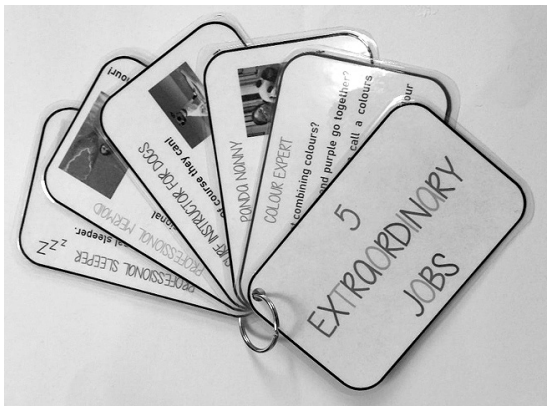

Slika 7 Knjižica nenavadnih poklicev

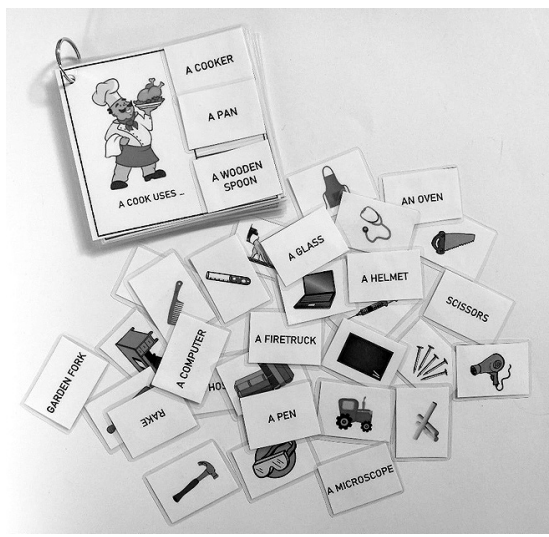

Slika 8 Razvrščanje orodij in pripomočkov k poklicem (najnižja težavnostna stopnja)

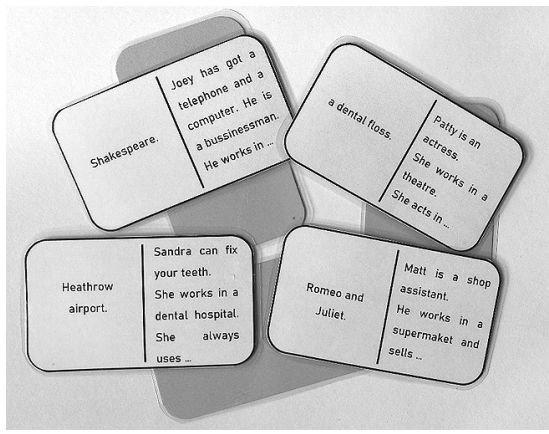

Slika 10 Domine (težka stopnja)

Slika 9 Domine (lahka stopnja)

umikamo vidno podporo, kar še posebej izstopa pri dominah. Te se osredotočajo predvsem na povezovanje poklica in prostora, kjer osebe ta poklic opravljajo. Igra je zasnovana kot individualna dejavnost ali dejavnost v paru. $\mathrm{Na}$ najlažji stopnji učenci povezujejo poklic z ustreznim prostorom oz. delovnim okoljem, pri tem so jim v pomoč opisi ter slike poklica in kraja, kjer se le-ta opravlja (slika 9).

Pri zelenih dominah smo umaknili vizualno podporo pri opisu poklica, slika je tako ostala le za prostor, kjer se poklic opravlja, pri modrih dominah, ki predstavljajo dejavnost na najvišji težavnostni stopnji (slika 10), pa smo umaknili vso vidno podporo in ohranili le opise. Igro smo otežili tudi tako, da učenci ne povezujejo poklica in pripadajočega delovnega prostora, ampak točno določen kraj, kot je letališče Heathrow ali osnovna šola Novo mesto. 

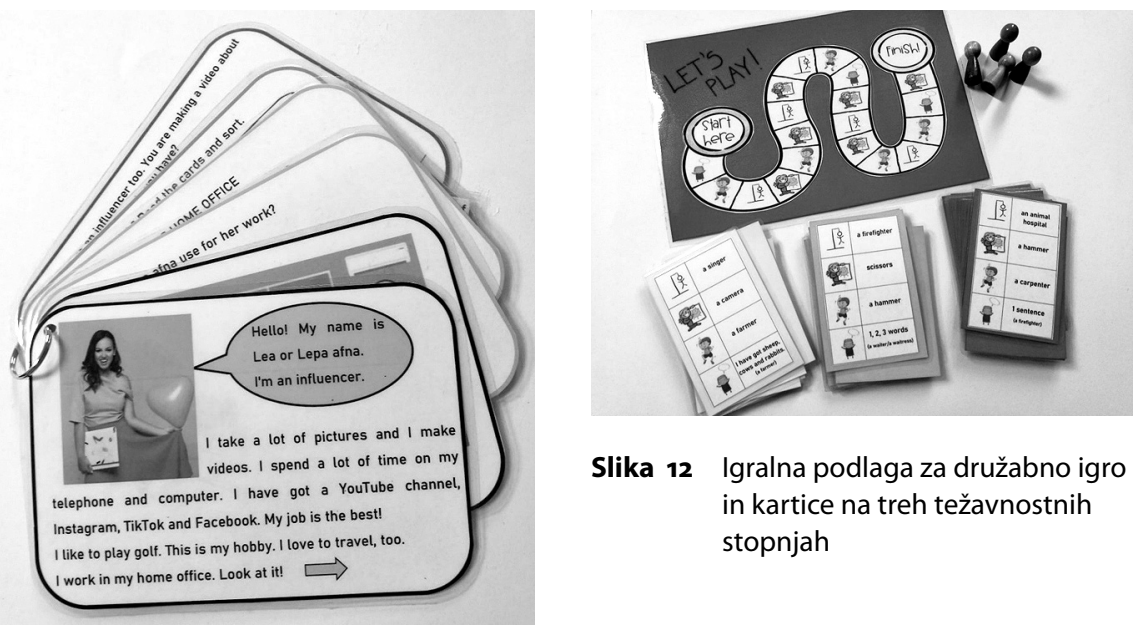

Slika 12 Igralna podlaga za družabno igro in kartice na treh težavnostnih stopnjah

Slika 11 Bralna knjižica z besedilom o poklicu vplivneža in pripadajoče dejavnosti

Bralni knjižici z dejavnostmi. V knjigo za naročje sta vključeni dve knjižici, in sicer knjižica o poklicu gasilca in druga o poklicu vplivneža (slika 11). Oba poklica sta predstavljena s kratkim besedilom, temu pa so dodane tudi naloge na treh težavnostnih stopnjah. Na prvi stopnji so to naloge za razvijanje besedišča in bralnega razumevanja, na srednji težavnostni stopnji učenci ponovijo znanje predlogov in ugotavljajo razlike med poklicem ter hobijem, na najvišji težavnostni stopnji pa uvajamo tudi samostojno pisanje kratkih besedil.

Družabna igra. Zadnja dejavnost v knjigi za naročje o poklicih je družabna igra, oblikovana po zgledu igre Activity, v kateri učenci ponovijo besedišče, ki so ga spoznali preko ostalih dejavnosti. Igra je sestavljena iz igralne podlage, figuric in kartic na treh težavnostnih stopnjah (slika 12), na katerih so besede ali besedne zveze, ki jih učenci svojim soigralcem predstavijo preko igre vislice, $z$ risanjem, s pantomimo ali z razlago. Didaktična igra je zanimiva za učence $z$ razvito jezikovno, prostorsko, telesno-gibalno in medosebno inteligentnostjo, saj vsebuje paleto različnih dejavnosti, združenih v eno skupinsko dejavnost.

\section{Knjiga za naročje Jobs z vidika četrtošolcev}

Evalvacija didaktičnega pripomočka temelji na povratni informaciji učencev, ki so knjigo za naročje preizkusili, in sicer na njihovem splošnem mnenju o učilu in njegovem vplivu na njihovo učno motivacijo ter o učni temi in težav- 
nostnih stopnjah. Učencem smo ponudili nekaj pridevnikov in jih pozvali, naj izberejo tiste, $s$ katerimi bi opisali knjigo za naročje. 20 jih je knjigo označilo kot zabavno, 17 kot zanimivo, 16 kot koristno, štiri kot nezahtevno, nihče pa je ni ocenil kot dolgočasno.

Na vprašanje o tem, kaj jim je bilo pri knjigi za naročje najbolj všeč, je večina učencev (devet) zapisala, da je bila to samostojna izbira težavnosti, nekateri (štirje) pa, da so se s knjigo lahko igrali. En učenec je zapisal, da mu je bilo všeč, da v njej ni bilo potrebno veliko pisati, kar je pričakovan odziv, saj začnemo pri angleščini kot tujem jeziku pisno zmožnost aktivno razvijati šele proti koncu tretjega razreda, pisanje pa tako za mnoge učence četrtega razreda še vedno predstavlja precejšen izziv. Ob vprašanju, kaj jim ob delu s knjigo za naročje ni bilo všeč, so nekateri učenci potožili le, da se jim je tema zdela prezahtevna. Dva sta zapisala, da nista razumela nekaterih besed, dva pa, da občasno nista znala rešiti nalog. En je zapisal tudi, da knjiga za naročje nima dovolj nalog oz. je prekratka. Da bi si v bodoče še želeli uporabljati knjigo za naročje, je zapisala večina (16) učencev.

Zanimalo nas je tudi, kako so učenci ocenili svojo motivacijo za uporabo didaktičnega sredstva. Največ (deset) jih je didaktično sredstvo vzelo v naročje trikrat do štirikrat $v$ treh tednih, večina ostalih pa enkrat do dvakrat. Le dva učenca sta knjigo za naročje uporabila petkrat ali večkrat. Najzanimivejše so se jim zdele različne igre, in sicer tombola, paličice za sestavljanje povedi, družabna igra, knjiga Paula the Vet in domine pa tudi risanje nenavadnega hišnega ljubljenčka ter uganke o poklicih. Omenjene igre so oblikovane za različne učne stile in inteligentnosti, kar je značilnost diferenciranih vsebin (Tomlinson 200o). En učenec je zapisal, da mu je všeč oblika knjige, in sicer to, »da ima veliko žepkov in zaponk, ki se odpirajo in zapirajo«. Večini učencev se je učenje angleščine s knjigo za naročje zdelo zabavno, zanimivo in učinkovito. Predvsem so jim bile všeč vsebina (da je bilo v njej veliko zabavnih iger, da so se naučili veliko besed o poklicih, da so izvedeli kar nekaj novega o poklicih), avtonomija pri uporabi pripomočka (da so lahko sami izbirali naloge za reševanje, da so lahko sami izbrali težavnostno stopnjo, da so jo lahko uporabljali, kadar so želeli) ter socialna in sodelovalna komponenta (da so se lahko igrali, pogovarjali s prijatelji in se ob tem zabavali).

Pri vprašanju o izbrani temi so navedli, da se jim tema o poklicih ni zdela prezahtevna, za večino je bila zanimiva in jim je predstavljala določen izziv. Poleg tega so bili mnenja, da so $s$ knjigo za naročje izgrajevali novo znanje o poklicih, nihče pa ni izpostavil, da se ni ničesar novega naučil.

Prav tako smo želeli izvedeti, kako so učenci dojemali težavnostne stopnje $v$ didaktičnem sredstvu in katere dejavnosti so izbirali najbolj. Uporaba 
različnih težavnostnih stopenj je namreč uveljavljen način diferenciranja dejavnosti (Tomlinson 2000). Pričakovano se jih je največ odločilo za ukvarjanje $z$ dejavnostmi rumene in zelene stopnje, torej lahke in srednje težke dejavnosti, le dva učenca sta se največkrat posvetila dejavnostim najtežje stopnje. Izvedeti smo želeli, ali so učenci razumeli besedišče, uporabljeno v knjigi za naročje, in izkazalo se je, da s tem niso imeli težav. Največ (15) jih je razumelo večino besed, le dva sta potožila, da to zanju ne drži. V skladu s tem je tudi ugotovitev, da jih več kot polovica pri delu s knjigo za naročje ni potrebovala pomoči učiteljice, šest učencev je za pomoč zaprosilo, a ne pogosto, le trije so večkrat zaprosili za pomoč učiteljice. Zanimiv je tudi podatek, da je bila večini (14) všeč samostojnost pri izbiri težavnostne stopnje dejavnosti v didaktičnem sredstvu.

Iz rezultatov vprašalnika ugotavljamo, da so učenci knjigo za naročje sprejeli kot zanimivo in uporabno. Izpostaviti velja predvsem dober odziv na dejavnosti, ki so zasnovane po načelu igre, še posebej tiste, ki vključujejo socialno in sodelovalno komponento, značilno za inovativna učna okolja (Dumont, Istance in Benavides 2013), ter na avtonomijo pri uporabi pripomočka, in sicer samostojno izbiranje nalog, časa učenja in težavnostnih stopenj, kar pa je pomemben element prostorov učenja, kot jih razume $C$. Damşa s sodelavci (2019). Individualno učenje je v učencih vzbudilo zadovoljstvo, ki je bilo enako izrazito pri tistih, ki so se ukvarjali z lažjimi, kot pri tistih, ki so se ukvarjali s težjimi dejavnostmi. Sklepamo lahko torej, da so s pripomočkom radi delali učenci z različnim predznanjem in različnimi ravnmi jezikovne sporazumevalne zmožnosti, kar je bistveno za diferenciran in individualiziran pouk (Tomlinson 2000).

\section{Zaključek}

$\checkmark$ prispevku je predstavljen primer izdelave didaktičnega pripomočka, ki služi kot alternativno učno okolje za namene diferenciacije pri pouku angleščine na zgodnji stopnji. Izbrali smo format knjige za naročje, ki je v slovenskem šolskem prostoru še relativno neznan, po svojih značilnostih pa primeren za diferenciacijo in individualizacijo učenja tujega jezika. Glavni poudarki pri oblikovanju knjige za naročje so bili izbira tematike in določitev učnih ciljev ter oblikovanje diferenciranih dejavnosti, pri čemer smo upoštevali kriterije za oblikovanje inovativnih učnih okolij. Med temi so se kot ključni izkazali zagotavljanje socialne in sodelovalne dimenzije učenja, občutljivost za individualne razlike med učenci ter upoštevanje pomena motivacije in čustev za učenje. Izdelano knjigo za naročje so preizkusili učenci četrtega razreda ene izmed slovenskih osnovnih šol. Iz njihovih odzivov lahko zaključimo, da se je 
knjiga za naročje izkazala kot ustrezen pripomoček za diferenciacijo učenja in hkrati spodbudno učno okolje, ki uspešno vključuje vse učence ne glede na njihovo predznanje, stopnjo jezikovne sporazumevalne zmožnosti, interese in učne stile ter jim tako zagotovi enake možnosti za usvajanje znanja. Učenci so še posebej pohvalili dejavnosti, zasnovane po načelu igre, predvsem tiste s socialno in sodelovalno komponento, ter avtonomijo pri uporabi pripomočka.

$V$ didaktičnem sredstvu knjiga za naročje vidimo možnost za široko uporabo $v$ razredu, še posebej pri diferenciaciji in individualizaciji pouka ter samostojnem delu učencev $v$ obliki alternativnega učnega okolja znotraj šolskega prostora, $v$ katerega učenci lahko prehajajo ne le $v$ okviru pouka, pač pa tudi med odmori in $v$ podaljšanem bivanju. Zavedamo se časovne zamudnosti ob oblikovanju podobnih didaktičnih sredstev, zato bi veljalo knjigo za naročje vpeljati kot samostojni izdelek učencev, recimo kot zbirko dejavnosti na določeno temo, pri čemer učitelj nudi pomoč in vodenje, učenec pa sam izdela knjigo za naročje in s tem svoj prostor učenja.

\section{Literatura}

Bratož, S. 2017. »Pristopi k poučevanju tujega jezika s sodobne perspektive.« V Razsežnosti sodobnih učnih okolij, ur. S. Bratož, 221-240. Koper: Založba Univerze na Primorskem.

Bratož, S., in M. Žefran. 2014. „Creativity in Routine: Developing Learners' Oral Proficiency with T-Time.« V Izobraževanje za 21. stoletje - ustvarjalnost v vzgoji in izobraževanju, ur. D. Hozjan, 23-31. Koper: Annales.

Brewster, J., G. Ellis in D. Girard. 2010. The Primary English Teacher's Guide. Harlow: Penguin English.

Damşa, C., N. Nerland in Z. E. Andreadakis. 2019. »An Ecological Perspective on Learner-Constructed Learning Spaces. «British Journal of Educational Technology 50 (5): 2075-2089.

Donaldson, J. 2006. Paula the Vet. Oxford: Oxford Reading Tree.

Dumont, H., D. Istance in F. Benavides, ur. 2013. O naravi učenja: uporaba raziskav za navdih prakse. Prev. S. Sentočnik idr. Ljubljana: Zavod Republike Slovenije za šolstvo.

Echevarria, J., M. Vogt in D. Short. 2004. Making Content Comprehensible for English Learners: The SIOP Model. Boston, MA: Allyn \& Bacon.

Heacox, D. 2009. Diferenciacija za uspeh vseh: predlogi za uspešno delo z učenci različnih zmožnost; preizkušeni nasveti in zamisli za učinkovito poučevanje. Prev. Z. Pengal. Ljubljana: Rokus Klett.

Hudson, P. 2014. Lapbooking through Habitats. 2. izd. Elemental Science. Ireson, J., in S. Hallam. 2001. Ability Grouping in Education. London: Sage. Lange, C. M., in S. J. Sletten. 2002. Alternative Education: A Brief History and Re- 
search Synthesis. Alexandria, VA: National Association of State Directors of Education.

Lesničar, B. 2004. »Diferenciacija pri pouku angleščine v 9-letni osnovni šoli.« V Diferenciacija in nivojski pouk v prenovljeni šoli, ur. M. Kramar, 89-92. Maribor: Supra.

Lightbown, P. M., in N. Spada. 2013. How Languages Are Learned. Oxford: Oxford University Press.

Ministrstvo za izobraževanje, znanost in šport. 2016. Program osnovna šola: angleščina; učni načrt. Ljubljana: Ministrstvo za izobraževanje, znanost in šport in Zavod Republike Slovenije za šolstvo.

OECD. 2013. Innovative Larning Environments, Educational Research and Innovation. Pariz: OECD.

Pinter, A. 2006. Teaching Young Language Learners. Oxford: Oxford University Press.

Poljak, V. 1974. Didaktika. Ljubljana: DZS.

Pravilnik o izvajanju diferenciacije v osnovni šoli. 2006. Uradni list Republike Slovenije, št. 63. https://www.uradni-list.si/1/objava.jsp?sop=2006-01-2720.

Rickard, K. J. 2017. »Lapbooks: Adding Creativity to Literature-Based Intervention. "Perspectives of the ASHA Special Interest Groups 2 (1): 5-19.

Stonehouse, A. 2011. »The 'Third Teacher' - Creating Child Friendly Learning Spaces."Putting Children First 38:12-14.

Strmčnik, F. 1987. Sodobna šola v luči učne diferenciacije in individualizacije. Ljubljana: Zveza organizacij za tehnično kulturo Slovenije, Izobraževalna skupnost Slovenije.

- 2001. Didaktika: osrednje teoretične teme. Ljubljana: Znanstveni inštitut Filozofske fakultete.

Tomlinson, C. A. 2000. »Differentiation of Instruction in the Elementary Grades.« https://pdst.ie/sites/default/files/A.\%20Alt\%20ar\%20Dhifre\%C3 $\% \mathrm{~A}_{1} \mid \% \mathrm{C}_{3} \% \mathrm{BA} \% 20$ le\%20Thomlinson.pdf.

- 2001. How to Differentiate Instruction in Mixed-Ability Classrooms. Alexandria, VA: ASCD.

-2003. Fulfilling the Promise of the Differentiated Classroom: Strategies and Tools for Responsive Teaching. Alexandria, VA: ASCD.

Valenčič Zuljan, M., M. Cotič, D. Felda, Z. Magajna in A. Žakelj. 2012. »Kazalniki socialnega kapitala, kulturnega kapitala in šolske klime v napovedovanju šolske uspešnosti otrok in mladostnikov.« Zaključno poročilo o rezultatih ciljnega raziskovalnega projekta. http://www.mizs.gov.si/fileadmin/mizs .gov.si/pageuploads/podrocje/razvoj_solstva/evalvacija.

Whittaker, J. 2008. »Lapbooking 101: What Is a Lapbook?« http://lapbooking .wordpress.com/lapbook/.

Zakon o osnovni šoli (ZOsn-UPB3). 2006. Uradni list Republike Slovenije, št. 81. https://www.uradni-list.si/1/objava.jsp?sop=2006-01-3535. 
Zorman, A. 2008. »Didaktična gradiva za začetno opismenjevanje v drugem oziroma v tujem jeziku. $V$ Sodobne strategije učenja in poučevanja, ur. V. Medved Udovič, M. Cotič in M. Cencič, 57-78. Koper: Pedagoška fakulteta.

\section{The Lap Book as an Alternative Learning Environment for Differentiated Foreign Language Learning}

Heterogeneous classes present a considerable challenge for teachers who want to provide all their students with equal opportunities for knowledge acquisition. An effective answer to this is differentiated and individualized learning environments. In this paper, we present an example of good practice - creating an environment for differentiation of EFL learning in the lower grades of primary school in the form of a lap book. The lap book was tested with fourth graders at one of the Slovenian primary schools. Pupils were able to move into the differentiated learning environment of the lap book during class or during breaks. Based on their feedback, we can conclude that the lap book is a suitable tool for all learners regardless of their prior knowledge, language communication skills, interests and learning styles. Pupils especially liked game-like activities with a strong social and collaborative component, as well as the autonomous use of the tool.

Keywords: lap book, alternative learning environment, differentiated classroom, foreign language learning, primary school 